\title{
Phytoprotection
}

\section{The effect of two ectomycorrhizal fungi, Paxillus involutus and Suillus tomentosus, and of Bacillus subtilis on Fusarium damping-off in jack pine seedlings}

\author{
S.F. Hwang, P. Chakravarty et K.-F. Chang
}

Volume 76, numéro 2, 1995

URI : https://id.erudit.org/iderudit/706085ar

DOI : https://doi.org/10.7202/706085ar

Aller au sommaire du numéro

Éditeur(s)

Société de protection des plantes du Québec (SPPQ)l

ISSN

0031-9511 (imprimé)

1710-1603 (numérique)

Découvrir la revue

Citer cet article

Hwang, S., Chakravarty, P. \& Chang, K.-F. (1995). The effect of two ectomycorrhizal fungi, Paxillus involutus and Suillus tomentosus, and of Bacillus subtilis on Fusarium damping-off in jack pine seedlings. Phytoprotection, 76(2), 57-66. https://doi.org/10.7202/706085ar
Résumé de l'article

On a testé l'effet de deux espèces de champignons ectomycorhiziens, le Paxillus involutus et le Suillus tomentosus, et une lignée de la bactérie Bacillus subtilis sur le Fusarium moniliforme, agent pathogène de la fonte des semis du pin gris (Pinus banksiana). Le $P$. involutus et $B$. subtilis ont tous les deux inhibé la croissance in vitro du $F$ moniliforme. Les filtrats de culture de $P$. involutus et de $B$. subtilis ont été toxiques pour le $F$ moniliforme, mais la formation de chlamydospores par le $F$ moniliforme a été observée. Une meilleure survie des plantules a été observée lorsqu'elles étaient co-inoculées avec le $P$. involutus et le $B$. subtilis plutôt qu'avec le $F$ moniliforme seulement. Le $S$. tomentosus n'a pas inhibé la croissance in vitro du $F$. moniliforme ni accru la survie des plantules de pin gris en présence de $F$ moniliforme. Ce dernier a réduit la formation d'ectomycorhizes sur le pin gris par le $P$. involutus et le $S$. tomentosus. Le nombre d'unités formatrices de colonies du F. monoliforme a été significativement réduit quand les plantules ont été inoculées avec le $P$. involotus ou le B. subtilis seul ou en combinaison. D'autre part, le $S$. tomentosus n’a pas réduit le nombre d'unités formatrices de colonies du $F$. monoliforme. La suppression de la croissance du $F$. monoliforme par le $P$. involutus et le $B$. subtilis a entraîné la production de composés antifongiques.
Ce document est protégé par la loi sur le droit d'auteur. L'utilisation des services d'Érudit (y compris la reproduction) est assujettie à sa politique d'utilisation que vous pouvez consulter en ligne.

https://apropos.erudit.org/fr/usagers/politique-dutilisation/ 


\title{
The effect of two ectomycorrhizal fungi, Paxillus involutus and Suillus tomentosus, and of Bacillus subtilis on Fusarium damping-off in jack pine seedlings
}

\author{
Sheau-Fang Hwang ${ }^{1}$, Priyotosh Chakravarty ${ }^{2}$, and Kan-Fa Chang ${ }^{3}$
}

Received 1995-04-05; accepted 1995-10-29

Two species of ectomycorrhizal fungi, Paxillus involutus and Suillus tomentosus, and a bacterial strain of Bacillus subtilis, were tested against Fusarium moniliforme, the causal agent of damping-off in jack pine (Pinus banksiana) seedlings. Both $P$. involutus and $B$. subtilis inhibited in vitro growth of $F$. moniliforme. The culture filtrates of $P$. involutus and $B$. subtilis were toxic to F. moniliforme, but chlamydospore formation of F. moniliforme was observed. Greater jack pine seedling survival was observed when co-inoculated with $P$. involutus and $B$. subtilis than with $F$. moniliforme alone. $S$. tomentosus neither inhibited in vitro growth of $F$. moniliforme nor increased survival of jack pine seedlings against $F$. moniliforme. $F$. moniliforme reduced ectomycorrhiza formation on jack pine seedlings by $P$. involutus and $S$. tomentosus. The number of colony forming units of $F$. moniliforme was significantly reduced when seedlings were inoculated with $P$. involutus and $B$. subtilis alone or in combination. $S$. tomentosus, on the other hand, did not reduce the number of colony forming units of $F$. moniliforme. The suppression of $F$. moniliforme growth by $P$. involutus and $B$. subtilis involved production of antifungal compounds.

Hwang, S.-F., P. Chakravarty et K.-F. Chang. 1995. Effet de deux champignons ectomycorhiziens, le Paxillus involutus et le Suillus tomentosus, et du Bacillus subtilis sur la fonte des semis du pin gris. PHYTOPROTECTION 76 : 57-66.

On a testé l'effet de deux espèces de champignons ectomycorhiziens, le Paxillus involutus et le Suillus tomentosus, et une lignée de la bactérie Bacillus subtilis sur le Fusarium moniliforme, agent pathogène de la fonte des semis du pin gris (Pinus banksiana). Le $P$. involutus et $B$. subtilis ont tous les deux inhibé la croissance in vitro du $F$. moniliforme. Les filtrats de culture de $P$. involutus et de $B$. subtilis ont été toxiques pour le $F$. moniliforme, mais la formation de chlamydospores par le $F$. moniliforme a été observée. Une meilleure survie des plantules a été observée lorsqu'elles étaient co-inoculées avec le $P$. involutus et le $B$. subtilis plutôt qu'avec le $F$. moniliforme seulement. Le $S$. tomentosus n'a pas inhibé la croissance in vitro du F. moniliforme ni accru la survie des plantules de pin gris en présence de $F$. moniliforme. Ce dernier a réduit la formation d'ectomycorhizes sur le pin gris par le $P$. involutus et le

1. Biological Sciences, Alberta Environmental Centre, Bag 4000, Vegreville, Alberta, Canada T9C 1 T4

2. Natural Resources Canada, Canadian Forest Service, Northern Forestry Centre, 5320-122 Street, Edmonton, Alberta, Canada T6H 3S5. Author to whom correspondence should be addressed

3. Agriculture, Food, and Rural Development, SS4, Brooks, Alberta, Canada T1R $1 E 6$ 
S. tomentosus. Le nombre d'unités formatrices de colonies du F. moniliforme a été significativement réduit quand les plantules ont été inoculées avec le $P$. involutus ou le $B$. subtilis seul ou en combinaison. D'autre part, le $S$. tomentosus n'a pas réduit le nombre d'unités formatrices de colonies du $F$. moniliforme. La suppression de la croissance du F. moniliforme par le $P$. involutus et le $B$. subtilis a entraîné la production de composés antifongiques.

\section{INTRODUCTION}

Fusarium damping-off, caused by several species of Fusarium, is responsible for considerable losses in both container and bare root nurseries in North America (Filer and Peterson 1975; Hiratsuka 1987; Sutherland and Van Eerden 1980). The inoculum of the fungus can be carried on seed, contaminated growing media or in water. Various fungicides are used to control this disease. However, many of these fungicides are not very effective and do not protect the seedlings during their stay in the nurseries (Sinclair et al. 1975). In recent years, several root pathogens have been found to be resistant to many fungicides (Chakravarty and Kean, unpublished data). In addition to fungicides, proper fertility management may also reduce the incidence of dampingoff. Alternative non-chemical strategies for protecting nursery seedlings from various soil pathogens have received considerable attention in the last few decades (Adams 1990; Baker and Cook 1982). Reducing residual toxicity from chemicals in the soil is also essential for maintaining the operation of forest tree nurseries environmentally acceptable.

Bacillus subtilis (Ehrenberg) Cohn, a soil-inhabiting bacterium, has been used to control diseases of field crops. The bacterium produces antifungal substances which are toxic to several plant pathogens (Hall and Davis 1990; Jordon and Tarr 1987; Krause et al. 1987; Krezel and Leszczynska 1978; Podile et al. 1985; Pusey and Wilson 1984; Pusey et al. 1986; Singh and Deverall 1984; Utkhede 1984; Utkhede and Sholberg 1986). Although B. subtilis has potential for biological control in agricultural and horticultural crops, our knowledge on the effect of $B$. subtilis on forest tree seedlings is limited.

Paxillus involutus (Batsch.) Fr. and Suillus tomentosus (Kauffman) Singer, Snell, \& Dick, two species of ectomycor- rhizal fungi, form abundant ectomycorrhizae with pine (Pinus spp.) seedlings. $P$. involutus is known to protect seedlings of red pine (Pinus resinosa Ait.) from damping-off pathogens by producing antifungal substances (Chakravarty et al. 1990, 1991; Duchesne et al. 1987a,b, 1988, $1989 a, b)$. The effect of $S$. tomentosus on root pathogens of pines is not known. Marx $(1972,1973)$ and Zak (1964) hypothesized that root protection by ectomycorrhizal fungi may be the result of a protective barrier effect caused by the presence of a fungal mantle around the roots, nutrient competition in the rhizosphere, or production of antimicrobial substances either by the mycosymbiont or by the host plant. The effectiveness of the fungal symbiont for protecting against root diseases varies with the mycorrhizal species or isolate, host species, and soil conditions (Chakravarty and Unestam 1986, 1987a,b; Sampangi and Perrin 1985).

The objectives of this study were to investigate the interactions between $P$. involutus, $S$. tomentosus, B. subtilis, and $F$. moniliforme alone or in combination in the rhizosphere of jack pine (Pinus banksiana Lamb.) seedlings and to evaluate the mechanism of protection as hypothesized by Marx $(1972,1973)$ and Zak (1964).

\section{MATERIALS AND METHODS}

\section{Organisms}

Jack pine seedlings were used in this study. The root pathogen F. moniliforme, isolated from diseased jack pine seedlings in a greenhouse at the Northern Forestry Centre (Edmonton, Alberta, lat. $53^{\circ} 30^{\prime} \mathrm{N}$ long. $114^{\circ} 30^{\prime} \mathrm{W}$ ) was used throughout the experiment. Two species of ectomycorrhizal fungi, $P$. involutus and $S$. tomentosus (isolated from fruiting bodies collected from Edmonton, and a soilinhabiting bacterium, B. subtilis (isolated 
from forest soil collected near Hinton, Alberta, lat. $53^{\circ} 23^{\prime} \mathrm{N}$ long. $117^{\circ} 32^{\prime} \mathrm{W}$ ) were evaluated. The culture of $F$. moniliforme was maintained on potato dextrose agar (PDA), B. subtilis on nutrient agar (NA), and $P$. involutus and $S$. tomentosus on modified Melin Norkrans' (MMN) medium (Marx 1969).

\section{In vitro antagonism}

Antagonism between $F$. moniliforme and B. subtilis was studied on PDA in $90-\mathrm{mm}$ diam plastic Petri plates. Agar plugs (5-mm diam) with $F$. moniliforme were placed at the margin of the plate and allowed to grow at $20^{\circ} \mathrm{C}$ in the dark. After $3 \mathrm{~d}, B$. subtilis was streaked on the plate opposite the $F$. moniliforme colony $(4 \mathrm{~cm}$ apart). For the control, sterile distilled water was streaked on the plate opposite to the $F$. moniliforme colony. The plates were incubated as described above. The inhibition zone was measured from the edge of the $F$. moniliforme colony to the edge of the $B$. subtilis colony after $3 \mathrm{~d}$.

For antagonism of $P$. involutus and $S$. tomentosus against $F$. moniliforme, 5-mm-diam agar plugs of $P$. involutus and $S$. tomentosus (1-wk-old cultures) were placed separately at the margin of plates containing PDA, and allowed to grow at $20^{\circ} \mathrm{C}$ in the dark. After $7 \mathrm{~d}$, a 5-mm mycelial disk was removed from the PDA culture of $F$. moniliforme and placed on the plate opposite $P$. involutus and $S$. tomentosus (4 $\mathrm{cm}$ apart). For the control, $5-\mathrm{mm}$-diam sterile agar plugs were placed opposite to the F. moniliforme colony. The plates were incubated at $20^{\circ} \mathrm{C}$ in the dark. The inhibition zone was measured after 3-5 $d$ and the mycelia of $P$. involutus and $S$. tomentosus were observed under a microscope at a contact point with $F$. moniliforme.

\section{Effect of culture filtrates of antagonists on spore germination of $F$. moniliforme}

Paxillus involutus and $S$. tomentosus were grown in liquid $\mathrm{MMN}$ medium at $20^{\circ} \mathrm{C}$ in the dark in a shaker. After $10 \mathrm{~d}$, the mycelium was harvested on a Whatman No.1 filter paper and ethyl acetate was added to the filtrate to extract polar metabolites. The resulting solution was stored at $5^{\circ} \mathrm{C}$ in the dark. Similarly, culture filtrate of $B$. subtilis was prepared by growing it in $50 \mathrm{~mL}$ nutrient broth at $20^{\circ} \mathrm{C}$ in the dark in a shaker. After $36 \mathrm{~h}$, the broth was filtered through a filter paper (5.5 $\mu \mathrm{m}$ pore size) and the filtrate was extracted with ethyl acetate. A spore suspension of $F$. moniliforme was prepared in saline solution $(0.08 \% \mathrm{NaCl})$. A drop of the spore suspension of $F$. moniliforme was placed on a cavity slide and $20 \mu \mathrm{L}$ of the culture filtrate of $P$. involutus, $S$. tomentosus or $B$. subtilis was added separately on the cavity slide containing spore suspension of $F$. moniliforme. The slides were incubated in a sterile moist chamber at $20^{\circ} \mathrm{C}$ for 6,12 , and $24 \mathrm{~h}$. Spore germination and formation of chlamydospores of $F$. moniliforme were determined by examination under a microscope. For each treatment, a total of 500 spores were counted.

\section{Interactions of antagonists and $F$. moniliforme in the rhizosphere of jack pine seedlings}

For this experiment, two systems were used to grow $P$. banksiana seedlings : a flask system and a tray system.

\section{Flask system}

Jack pine seeds were surface sterilized using $30 \% \mathrm{H}_{2} \mathrm{O}_{2}$ for $30 \mathrm{~min}$. Seeds were then washed 10 times with sterile distilled water and germinated in the dark on water agar. Erlenmeyer flasks $(250 \mathrm{~mL}$ ) were prepared by adding $100 \mathrm{~mL}$ vermiculite ( $\mathrm{pH}$ adjusted to 5.0$)$ and moistened with MMN liquid medium. The flasks were stoppered with a foam plug, wrapped with aluminium foil, and autoclaved for $45 \mathrm{~min}$ at $121^{\circ} \mathrm{C}$. Ten-day-old jack pine seedlings were transferred into the flasks (one seedling per flask) under aseptic conditions. Seedlings were inoculated with $P$. involutus, $S$. tomentosus, $B$. subtilis, and F. moniliforme. The control treatment was not inoculated with any fungal or bacterial inoculum. The following treatments resulted : i) $P$. involutus, ii) S. tomentosus, iii) B. subtilis, iv) $F$. moniliforme, v) P. involutus + F. moniliforme, vi) $S$. tomentosus + F. moniliforme, vii) $B$. subtilis + $F$. moniliforme, viii) $P$. involutus $+B$. subtilis $+F$. moniliforme, ix) S. tomentosus + B. subtilis + F. moniliforme, and $\mathrm{x}$ ) control. A 5-mL spore suspension $\left(10^{5}\right.$ spores $\left.\mathrm{mL}^{-1}\right)$ of $F$. moniliforme was added using a sterile pipette to each flask except the control, 
in the rhizosphere of jack pine seedlings. Control seedlings were inoculated with three 5-mm sterile MMN agar plugs and $2 \mathrm{~mL}$ of sterile distilled water. The flasks were kept in a growth chamber under a photoperiod of $16 \mathrm{~h}\left(100 \mu \mathrm{mol} \mathrm{m}{ }^{-2} \mathrm{~s}^{-1}\right.$ PAR, provided by fluorescent lamps) at $20^{\circ} \mathrm{C}$ and randomized every $5 \mathrm{~d}$. No fertilizer or water was added to the flasks. There were 25 seedlings per treatment. Seedlings were harvested after $10 \mathrm{wk}$. Seedling mortality, shoot and root length, total biomass, and number of mycorrhizal short roots were determined for each seedling.

\section{Tray system}

Jack pine seeds were surface sterilized using $30 \% \mathrm{H}_{2} \mathrm{O}_{2}$. Seeds were sown in a tray containing sterile vermiculite $(\mathrm{pH} 5.5)$ and inoculated with $5 \mathrm{~g}$ inoculum of $P$. involutus and $S$. tomentosus (grown in vermiculite). For the control, seeds were grown in trays containing sterile vermiculite without $P$. involutus and $S$. tomentosus inocula. The trays were kept in a growth chamber as described above. Tenday-old seedlings were transferred to plastic trays $(18 \mathrm{~cm} \times 45 \mathrm{~cm} \times 15 \mathrm{~cm})$ containing sterile moistened vermiculite. Twenty-five seedlings were planted in each tray. Two days later, seedlings were inoculated with a 24-h-old culture of $B$. subtilis by adding $1 \mathrm{~mL}$ cell suspension $\left(2 \times 10^{6}\right.$ cells $\left.\mathrm{mL}^{-1}\right)$ to the rhizosphere of each seedling. Two days after inoculation with $B$. subtilis, seedlings were inoculated by adding $1 \mathrm{~mL}$ spore suspension $\left(10^{5}\right.$ spores $\left.\mathrm{mL}^{-1}\right)$ of $F$. moniliforme in the rhizosphere of each seedling. The same 10 treatments as for the flask system were applied. There were 3 trays per treatment. Trays were returned to the growth chamber and randomized every $5 \mathrm{~d}$. Ten weeks later, seedlings were harvested. Seedling mortality, shoot and root length, total biomass, and number of mycorrhizal short roots were determined for each seedling.

\section{Population density of $F$. moniliforme in the rhizosphere of jack pine seedlings}

The dilution plate technique was used to determine the population density of $F$. moniliforme in the rhizospheric vermiculite of jack pine seedlings. The vermiculite was diluted with sterile distilled water and spread evenly on PDA medium. There were 25 replicates for each treatment. Plates were incubated at $20^{\circ} \mathrm{C}$ in the dark. Colonies of $F$. moniliforme were counted and identified after incubation for $4 \mathrm{~d}$. The number of colonies per plate was multiplied by the dilution factor to obtain total concentration (no. $\mathrm{g}^{-1}$ ) in vermiculite.

\section{Statistical analysis}

Data from all the experiments were analyzed by one-way ANOVA using SAS software (SAS Institute Inc. 1990). The individual means were compared using Scheffé's test for multiple comparison after arcsine transformation (Zar 1984).

\section{RESULTS}

\section{In vitro antagonism}

The growth of $F$. moniliforme was significantly inhibited when grown in dual culture either with $B$. subtilis or $P$. involutus. B. subtilis showed a greater inhibitory effect than $P$. involutus on agar plate studies (Fig. 1). The growth of $F$. moniliforme was not affected when grown in dual culture with $S$. tomentosus. In addition, inhibition zones were observed with $B$. subtilis and $P$. involutus but not with S. tomentosus. When observed under a microscope, mycelia of $P$. involutus and

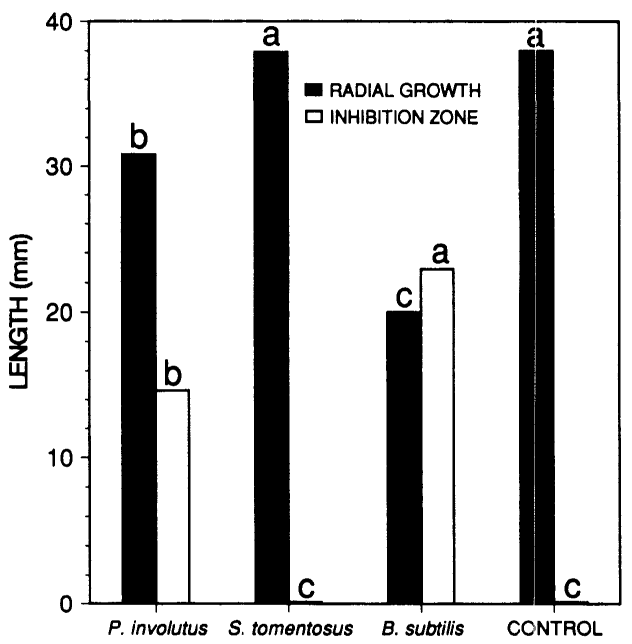

Figure 1. Inhibitory effect of Paxillus involutus, Suillus tomentosus, and Bacillus subtilis on radial growth and inhibition zone of Fusarium moniliforme on agar plates after 5 d incubation. 
S. tomentosus or cells of B. subtilis did not penetrate the mycelia or spores of F. moniliforme.

\section{Effect of culture filtrates of} antagonists on spore germination and chlamydospore formation of

\section{$F$. moniliforme}

The culture filtrates of $P$. involutus and B. subtilis significantly inhibited spore germination of $F$. moniliforme. The spore germination of $F$. moniliforme was $75 \%$ for controls whereas it was $30 \%$ when treated with culture filtrate of $P$. involutus and $41.4 \%$ when treated with culture filtrate of $B$. subtilis (Fig. 2). The spore

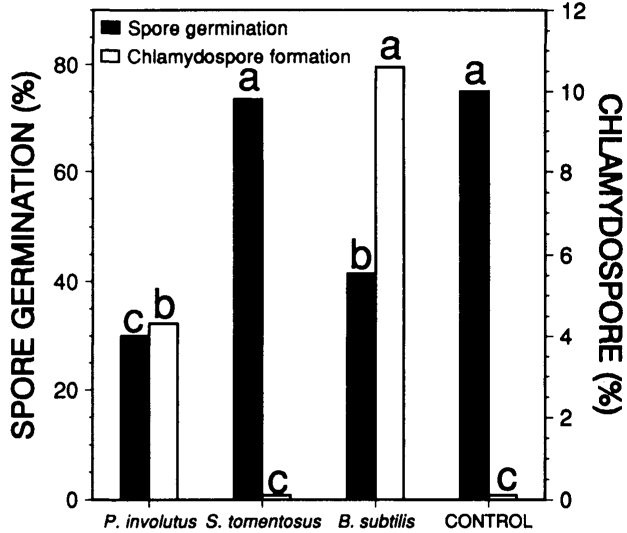

Figure 2. Effect of culture filtrates of Paxillus involutus, Suillus tomentosus and Bacillus involutus on spore germination and chlamydospore formation of Fusarium moniliforme. germination of $F$. moniliforme was not significantly reduced when treated with culture filtrate of $S$. tomentosus. The formation of chlamydospores of F. moniliforme was $10.6 \%$ when treated with culture filtrate of $B$. subtilis and only $4.3 \%$ when treated with culture filtrate of $P$. involutus. No chlamydospore formation was observed when treated with culture filtrate of $S$. tomentosus and nontreated controls (Fig. 2).

\section{Effect of antagonists on jack pine seedling mortality and disease development caused by $\boldsymbol{F}$. moniliforme}

\section{Flask system}

Both $P$. involutus and $B$. subtilis significantly increased survival of jack pine seedlings infected with $F$. moniliforme. F. moniliforme alone caused $84 \%$ seedling mortality (Table 1). When co-inoculated with $P$. involutus and $B$. subtilis, mortality of the seedlings was 20 and $28 \%$, respectively (Table 1 ). When both $P$. involutus and $B$. subtilis were concomitantly inoculated with $F$. moniliforme, seedling mortality was $16 \%$ (Table 1). $S$. tomentosus did not increase survival of seedlings when co-inoculated with F. moniliforme. Shoot height, root length, and total biomass of the seedlings were similar to the control when inoculated with $P$. involutus, $S$. tomentosus or $B$. subtilis (Table 1). Mycorrhizal formation by $P$. involutus and $S$. tomentosus

Table 1. Effect of Paxillus involutus (Pi), Suillus tomentosus (St), and Bacillus subtilis (Bs) on seedling mortality and disease development caused by Fusarium moniliforme (Fm) on jack pine grown in Erlenmeyer flasks

\begin{tabular}{lccccc}
\hline Treatment & $\begin{array}{c}\text { Seedling } \\
\text { mortality } \\
(\%)\end{array}$ & $\begin{array}{c}\text { Shoot } \\
\text { height } \\
(\mathrm{cm})\end{array}$ & $\begin{array}{c}\text { Root } \\
\text { length } \\
(\mathrm{cm})\end{array}$ & $\begin{array}{c}\text { Total } \\
\text { dry wt } \\
(\mathrm{mg})\end{array}$ & $\begin{array}{c}\text { No. of } \\
\text { mycorrhizal } \\
\text { short roots } \\
(\%)\end{array}$ \\
\hline Control & $0 \mathrm{dt}$ & $3.5 \mathrm{a}$ & $2.2 \mathrm{ab}$ & $74.0 \mathrm{~b}$ & 0 \\
$\mathrm{Fm}$ & $84.0 \mathrm{a}$ & $1.0 \mathrm{c}$ & $0.6 \mathrm{c}$ & $10.3 \mathrm{e}$ & 0 \\
$\mathrm{Bs}$ & $0 \mathrm{~d}$ & $3.1 \mathrm{ab}$ & $2.5 \mathrm{a}$ & $82.0 \mathrm{a}$ & 0 \\
$\mathrm{Pi}$ & $0 \mathrm{~d}$ & $3.0 \mathrm{ab}$ & $2.4 \mathrm{a}$ & $85.0 \mathrm{a}$ & $52.2 \mathrm{a}$ \\
$\mathrm{St}$ & $0 \mathrm{~d}$ & $3.2 \mathrm{ab}$ & $2.3 \mathrm{a}$ & $86.0 \mathrm{a}$ & $51.5 \mathrm{a}$ \\
$\mathrm{Bs}+\mathrm{Fm}$ & $28.0 \mathrm{~b}$ & $2.8 \mathrm{~b}$ & $1.9 \mathrm{~b}$ & $50.0 \mathrm{~d}$ & 0 \\
$\mathrm{Pi}+\mathrm{Fm}$ & $20.0 \mathrm{c}$ & $2.8 \mathrm{~b}$ & $2.4 \mathrm{a}$ & $57.0 \mathrm{c}$ & $35.0 \mathrm{~b}$ \\
$\mathrm{St}+\mathrm{Fm}$ & $82.5 \mathrm{a}$ & $1.2 \mathrm{c}$ & $0.7 \mathrm{c}$ & $9.5 \mathrm{e}$ & $10.0 \mathrm{c}$ \\
$\mathrm{Bs}+\mathrm{Pi}+\mathrm{Fm}$ & $16.0 \mathrm{c}$ & $2.8 \mathrm{~b}$ & $2.3 \mathrm{a}$ & $60.0 \mathrm{c}$ & $30.0 \mathrm{~b}$ \\
$\mathrm{Bs}+\mathrm{St}+\mathrm{Fm}$ & $27.5 \mathrm{~b}$ & $2.5 \mathrm{~b}$ & $1.7 \mathrm{~b}$ & $49.5 \mathrm{~d}$ & $10.0 \mathrm{c}$ \\
\hline
\end{tabular}

+ Means within a column followed by the same letter are not significantly different $(P=0.05)$ according to the Scheffé's test. 
was significantly decreased when seedlings were co-inoculated with F. moniliforme (Table 1).

\section{Tray system}

As in the Erlenmeyer flasks, both $P$. involutus and $B$. subtilis significantly increased survival of seedlings infected with F. moniliforme (Table 2). S. tomentosus did not increase survival of seedlings when co-inoculated with $F$. moniliforme. Shoot height, root length, and total biomass of the seedlings were significantly higher when co-inoculated with F. moniliforme and $P$. involutus or $B$. subtilis than with F. moniliforme alone (Table 2). My- corrhizal formation by $P$. involutus and $S$. tomentosus was significantly reduced when seedlings were co-inoculated with F. moniliforme (Table 2).

\section{Population density of $F$. moniliforme in the rhizosphere of jack pine seedlings inoculated with antagonists}

The colony forming units (cfu) of F. moniliforme were significantly reduced in both Erlenmeyer flasks and trays when inoculated with $P$. involutus or $B$. subtilis (Table 3). S. tomentosus did not reduce the numbers of cfu of $F$. moniliforme. However, no significant difference in

Table 2. Effect of Paxillus involutus (Pi), Suillus tomentosus (St), and Bacillus subtilis (Bs) on seedling mortality and disease development by Fusarium moniliforme (Fm) of jack pine seedlings grown in trays

\begin{tabular}{|c|c|c|c|c|c|}
\hline Treatment & $\begin{array}{c}\text { Seedling } \\
\text { mortality } \\
(\%)\end{array}$ & $\begin{array}{c}\text { Shoot } \\
\text { height } \\
(\mathrm{cm})\end{array}$ & $\begin{array}{l}\text { Root } \\
\text { length } \\
(\mathrm{cm})\end{array}$ & $\begin{array}{l}\text { Total } \\
\text { dry wt } \\
\text { (mg) }\end{array}$ & $\begin{array}{c}\text { No. of } \\
\text { mycorrhizal } \\
\text { short roots } \\
(\%)\end{array}$ \\
\hline Control & $0 \mathrm{ct}$ & $3.5 \mathrm{bc}$ & $3.5 \mathrm{a}$ & $85.0 \mathrm{a}$ & $d$ \\
\hline $\mathrm{Fm}$ & $76.0 \mathrm{a}$ & $2.0 \mathrm{~d}$ & $0.5 d$ & $12.3 \mathrm{c}$ & $0 \mathrm{~d}$ \\
\hline Bs & $0 \quad c$ & $4.0 \mathrm{ab}$ & $2.0 \mathrm{c}$ & $80.0 \mathrm{a}$ & $\begin{array}{ll}0 & d\end{array}$ \\
\hline $\mathrm{Pi}$ & $\mathrm{C}$ & $4.5 \mathrm{a}$ & $2.6 \mathrm{~b}$ & 86.0 a & $61.0 \mathrm{a}$ \\
\hline St & $0 \quad c$ & $4.0 \mathrm{ab}$ & $2.0 \mathrm{c}$ & $82.5 \mathrm{a}$ & $59.0 \mathrm{a}$ \\
\hline $\mathrm{Bs}+\mathrm{Fm}$ & $24.0 \mathrm{~b}$ & $3.0 \mathrm{c}$ & $2.0 \mathrm{c}$ & $58.0 \mathrm{~b}$ & $0 \mathrm{~d}$ \\
\hline $\mathrm{Pi}+\mathrm{Fm}$ & $20.0 \mathrm{~b}$ & $3.5 \mathrm{bc}$ & $2.6 \mathrm{~b}$ & $60.0 \mathrm{~b}$ & $30.0 \mathrm{~b}$ \\
\hline $\mathrm{St}+\mathrm{Fm}$ & $75.0 \mathrm{a}$ & $2.2 \mathrm{~d}$ & $0.6 \mathrm{~d}$ & $13.0 \mathrm{c}$ & $10.5 \mathrm{c}$ \\
\hline $\mathrm{Bs}+\mathrm{Pi}+\mathrm{Fm}$ & $20.0 \mathrm{~b}$ & $3.8 \mathrm{bc}$ & $2.6 b$ & $65.0 \mathrm{~b}$ & $30.2 b$ \\
\hline $\mathrm{Bs}+\mathrm{St}+\mathrm{Fm}$ & $25.0 \mathrm{~b}$ & $3.2 \mathrm{c}$ & $2.0 \mathrm{c}$ & $57.0 \mathrm{~b}$ & $10.0 \mathrm{c}$ \\
\hline
\end{tabular}

† Means within a column followed by the same letter are not significantly different $(P:=0.05)$ according to the Scheffé's test.

Table 3. Population density of Fusarium moniliforme $(\mathrm{Fm})$ in the rhizosphere of jack pine seedlings inoculated with Paxillus involutus (Pi), Suillus tomentosus ( $\mathrm{St}$ ), and Bacillus subtilis (Bs)

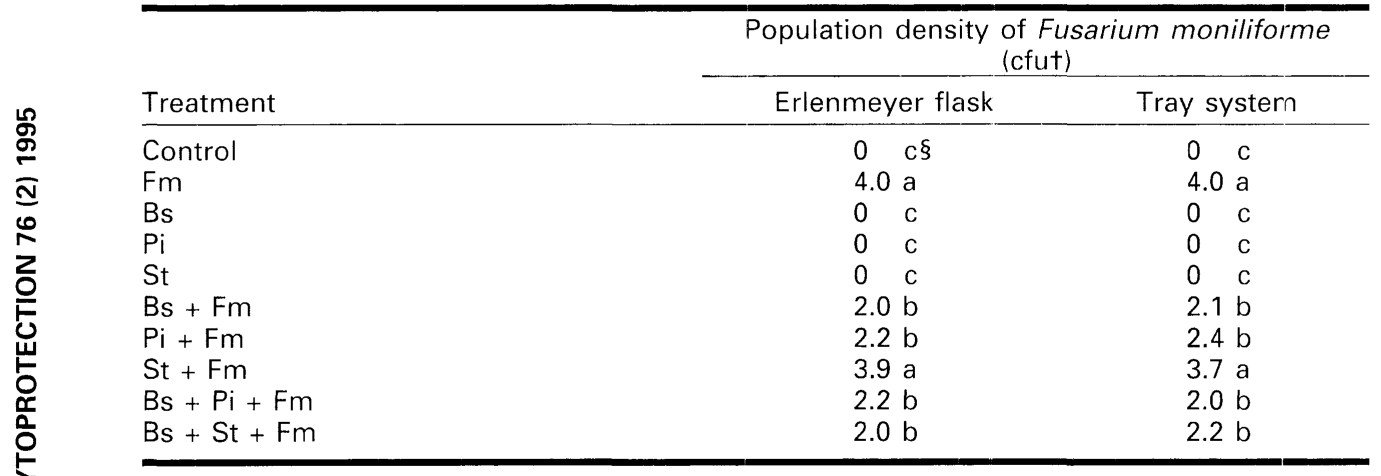

† Colony forming units.

$\S$ Means in a column followed by the same letter are not significantly different $(P:=0.05)$ according to the Scheffé's test. 
numbers of cfu of $F$. moniliforme was observed when seedlings were inoculated with $P$. involutus $+B$. subtilis + $F$. moniliforme and $S$. tomentosus + B. subtilis + F. moniliforme (Table 3).

\section{DISCUSSION}

In our study, the mycelium of $P$. involutus or cells of $B$. subtilis did not penetrate the mycelium or spores of $F$. moniliforme. The formation of dormant spores was observed when F. moniliforme was treated with culture filtrate of $P$. involutus. When jack pine seedlings were inoculated with $P$. involutus, it was observed that not only the mantle-covered short-root tips of jack pine were protected, but also the long tap roots without a mantle were protected against $F$. moniliforme. Many short roots without a mantle were also protected, while the roots not inoculated with $P$. involutus were susceptible. Thus, the mantle barrier hypotheses cannot explain the mechanism of protection. Our in vitro studies suggest that $P$. involutus produced inhibitory substances in the liquid medium which was toxic to F. moniliforme. Suillus tomentosus, on the other hand, did not produce substances that are inhibitory to F. moniliforme.

Several authors have reported that disease suppression by ectomycorrhizal fungi is associated with plant-produced antimicrobial substances (Chakravarty and Hwang 1991; Chakravarty and Unestam 1986, 1987a,b; Duchesne et al. 1987a,b, 1988, 1989a,b; Sampangi and Perrin 1985; Sylvia and Sinclair 1983a,b). Suppression of $F$. moniliforme dampingoff by $P$. involutus likely results from the production of antifungal compounds by $P$. involutus or production of antimicrobial compounds by the plant.

The number of cfu of $F$. moniliforme was significantly reduced in the rhizosphere of jack pine seedlings inoculated with $P$. involutus. This indicates that $P$. involutus produced antifungal substances in the rhizosphere of jack pine seedlings that limited the numbers of cfu of $F$. moniliforme. It has been suggested by several authors that ectomycorrhizae produce solvent-extractable volatile compounds which can inhibit several root pathogens (Graham and Linderman 1980; Krupa and Fries 1971; Krupa and Nylund 1972; Krupa et al. 1973; Schisler and Linderman 1989a,b). The production of volatiles by ectomycorrhizal fungi may be deleterious to several species of Fusarium (Chakravarty et al. 1991; Schisler and Linderman 1989b; Stack and Sinclair 1975). The formation of ectomycorrhizae on jack pine seedlings was also reduced when challenged with $F$. moniliforme. This suggests that $F$. moniliforme also produced antifungal compounds in the rhizosphere of jack pine seedlings that inhibited ectomycorrhiza formation by $P$. involutus. Chakravarty et al. (1991) made similar observations with several root pathogenic fungi including Fusarium spp.

As with $P$. involutus, $B$. subtilis also significantly inhibited in vitro growth of $F$. moniliforme and reduced mortality of jack pine seedlings. $B$. subtilis is known to be an active antagonistic bacterium against several root pathogens (Broadbent et al. 1971; Gordon et al. 1973; Hall and Davis 1990; Pusey et al. 1988; Singh and Deverall 1984; Utkhede and Sholberg 1986). The bacterium protects against or prevents root pathogens by secreting antimicrobial substances including several antibiotics such as bacilysin, fengymycin, bacitracin, bacillin, bulbiformin, mycosubtilin, and subtilin (Loeffler et al. 1986; Vanittanakom et al. 1986). In this study, B. subtilis significantly inhibited the in vitro growth of $F$. moniliforme. The culture filtrate of $B$. subtilis strongly inhibited spore germination but stimulated chlamydospore formation of F. moniliforme. Similar observations were also reported by Singh and Singh (1983). Our in vitro study indicates that inhibition of growth of $F$. moniliforme and formation of chlamydospores was related to the production of antifungal compounds by $B$. subtilis. The bacterium also reduced seedling mortality and decreased the population density of $F$. moniliforme in the rhizosphere of jack pine seedlings.

The biological protection provided by $B$. subtilis in this study was similar to that of $P$. involutus. When $P$. involutus and $B$. subtilis were co-inoculated, the effectiveness of both these organisms, however, remained the same. $P$. involutus and $B$. subtilis, on the other hand, did not 
show any inhibitory effect against each other. This suggests that these two organisms are compatible and can function in the presence of each other. In this study, $P$. involutus did not reduce the effectiveness of $B$. subtilis and vice versa. Thus $P$. involutus and $B$. subtilis are potentially compatible for biological protection against $F$. moniliforme dampingoff of jack pine. In this integrated system, both $P$. involutus and $B$. subtilis could provide protection at times when environmental factors are not favourable for the activity of either $P$. involutus or $B$. subtilis. S. tomentosus is not considered a potential candidate for biological control of $F$. monilifome. Further field studies are in progress to determine the effectiveness of $P$. involutus and $B$. subtilis and their interactions with other soil microorganisms, pathogens, and naturally occurring mycorrhizal fungi.

\section{ACKNOWLEDGEMENTS}

We thank Drs. L.M. Dosdall and L.J. Hutchison for reviewing this manuscript.

\section{REFERENCES}

Adams, P.B. 1990. The potential of mycoparasites for biological control of plant disease. Annu. Rev. Phytopathol. 28 : 59-72.

Baker, K.F., and R.J. Cook. 1982. Biological control of plant pathogens. Am. Phytopathol. Soc., St. Paul, Minnesota. 433 pp.

Broadbent, P., K.F. Baker, and Y. Waterworth. 1971. Bacteria and actinomycetes antagonistic to fungal root pathogens in Australian soils. Aust. J. Biol. Sci. 24 : 925-944.

Chakravarty, P., and S.F. Hwang. 1991. Effect of an ectomycorrhizal fungus, Laccaria laccata on Fusarium damping-off in Pinus banksiana seedlings. Eur. J. For. Pathol. $21:$ 97-106.

Chakravarty, P., and T. Unestam. 1986. Role of mycorrhizal fungi in preventing damping-off of Pinus sylvestris L. seedlings. Pages 811-814 in V. Gianinazzi-Pearson and S. Gianinazzi (eds.), Mycorrhizae : physiology and genetics. Proc. $1^{\text {st }}$ Eur. Symp. on Mycorrhizae, Dijon, France.
Chakravarty, P., and T. Unestam. 1987a. Mycorrhizal fungi prevent disease in stressed pine seedlings. Phytopathol. Z. 118 : 335340 .

Chakravarty, P., and T. Unestam. 1987b. Differential influence of ectomycorrhizae on plant growth and disease resistance in $\mathrm{Pi}$ nus sylvestris seedlings. Phytopathol. Z. $120: 104-120$.

Chakravarty, P., R.L. Peterson, and B.E. Ellis. 1990. Integrated control of Fusarium damping-off in red pine seedlings with the ectomycorrhizal fungus Paxillus involutus and fungicides. Can. J. For. Res. 20 : 12831288.

Chakravarty, P., R.L. Peterson, and B.E. Ellis. 1991. Interactions between the ectomycorrhizal fungus Paxillus involutus, dampingoff fungi, and Pinus resinosa seedlings. Phytopathol. Z. 132 : 207-218.

Duchesne, L.C., R.L. Peterson, and B.E. Ellis. 1987a. The accumulation of plant-produced antimicrobial compounds in response to ectomycorrhizal fungi : a review. Fhytoprotection 68 : 17-27.

Duchesne, L.C., R.L.Peterson, and B.E. Ellis. 1987b. Pine root exudate stimulates the synthesis of antifungal compounds by the ectomycorrhizal fungus Paxillus involutus. New Phytol. 108 : 471-476.

Duchesne, L.C., R.L. Peterson, and B.E. Ellis. 1988. Interaction between the ectomycorrhizal fungus Paxillus involutus and Pinus resinosa induces resistance to Fusarium oxysporum. Can. J. Bot. 66 : 558-562.

Duchesne, L.C., R.L. Peterson, and B.E. Ellis. 1989a. The time course of disease suppression and antibiosis by the ectomycorrhizal fungus Paxillus involutus. New Phytol. $111: 693-698$.

Duchesne, L.C., R.L Peterson, and B.E. Ellis. 1989b. The future of ectomycorrhizal fungi as biological control agents. Phytoprotection $70: 51-58$.

Filer, T.H., Jr., and G.W. Peterson. 1975. Damping-off. Pages 6-8 in: Forest nursery diseases in the United States. USD,A For. Serv., Washington, DC, Agric. Handbook 1975.

Gordon, R.F., W.C. Hayner, and H.N.C. Pang. 1973. The genus Bacillus. Agric. Handbook 1973, USDA. 427 pp.

Graham, J.H., and R.G. Linderman. 1980. Ethylene production by ectomycorrhizal fungi, Fusarium oxysporum f. sp. pini and by aseptically synthesized ectomycorrhizae and Fusarium infected Douglas-fir roots. Can. J. Microbiol. 26 : 1340-1347. 
Hall, T.J., and W.E. Davis. 1990. Survival of Bacillus subtilis in silver and sugar maple seedlings over a two-year period. Plant Dis. 74 : 608-609.

Hiratsuka, Y. 1987. Forest tree diseases of the prairie provinces. Information Rep. NORX-286, Can. For. Serv., Edmonton, Alberta, Canada. 141 pp.

Jordon, V.W.L., and H.S. Tarr. 1987. Inoculum suppression of Verticillium dahliae. Ann. Appl. Biol. 89 : 139-141.

Krause, C.R., J.M. Ichida, L.R. Schreiber, and G.F. Gregory. 1987. Morphological and cytological effects on Ceratocystis ulmi of an antifungal antibiotic produced by Bacillus subtilis. Phytopathology 77 : 1771 (Abstract).

Krezel, Z., and D. Leszczynska. 1978. Antibiotic activity of Bacillus subtilis to some phytopathogenic microorganisms. Meded. Fac. Landbouwwet. Rijksuniv. Gent. 43 : 859-865.

Krupa, S., and N. Fries. 1971. Studies on ectomycorrhizae of pine. I. Production of volatile organic compounds. Can. J. Bot. $49: 1425-1431$.

Krupa, S., and J.E. Nylund. 1972. Studies on ectomycorrhizae of pine. II. Growth inhibition of two root pathogenic fungi by volatile organic constituents of ectomycorrhizal root system of Pinus sylvestris. Eur. J. For. Pathol. 2 : 88-94.

Krupa, S., J. Andersson, and D.H. Marx. 1973. Studies on ectomycorrhizae of pine. IV. Volatile organic compounds in mycorrhizal and non-mycorrhizal root systems of Pinus echinata Mill. Eur. J. For. Pathol. 3 : 194-200.

Loeffler, W., J.S.M. Tschen, N. Vanittanakom, M. Krugler, E. Knorpp, T.T. Hsich, and T.G. Wu. 1986. Antifungal effects of bacilysin and fengymycin from Bacillus subtilis F-29-3: A comparison with activities of other Bacillus antibiotics. Phytopathol. Z. $115: 204-213$.

Marx, D.H. 1969. The influence of ectotrophic mycorrhizal fungi on the resistance of pine roots to pathogenic infections. I. Antagonism of mycorrhizal fungi to pathogenic fungi and soil bacteria. Phytopathology 59 : 153-163.

Marx, D.H. 1972. Ectomycorrhizae as biological deterrents to pathogenic root infections. Annu. Rev. Phytopathol. $10: 429$ 454.
Marx, D.H. 1973. Mycorrhizae and feeder root diseases. Pages 351-382 in G.C. Marks and T.T. Kozlowski (eds), Ectomycorrhizae their ecology and physiology. Acad. Press, New York.

Podile, A.R., G.S. Prasad, and H.C. Dube. 1985. Bacillus subtilis as antagonist to vascular wilt pathogens. Curr. Sci. 54 : 864-865.

Pusey, P.L., and C.L. Wilson. 1984. Postharvest biological control of stone fruit brown rot by Bacillus subtilis. Plant Dis. 68 : 753756.

Pusey, P.L., C.L. Wilson, M.W. Hotchkiss, and J.D. Franklin. 1986. Compatibility of Bacillus subtilis of postharvest control of peach brown rot with commercial fruit waxes, dichloran, and cold-storage conditions. Plant Dis. 70 : 587-590.

Pusey, P.L., M.W. Hotchkiss, H.T. Dulmage, R.A. Baumgardner, E.I. Zehr, C.C. Reilly, and C.L. Wilson. 1988. Pilot tests for commercial production and application of Bacillus subtilis (B-3) for postharvest control of peach brown rot. Plant Dis. 72 : 622 626.

Sampangi, R., and R. Perrin. 1985. Attempts to elucidate the mechanisms involved in the protective effect of Laccaria laccata against Fusarium oxysporum. Pages 799-806 in V. Gianinazzi-Pearson and S. Gianinazzi (eds.), Proc. $1^{\text {st }}$ Eur. Symp. on Mycorrhizae. Dijon, France.

SAS Institute Inc. 1990. SAS User's Guide. $4^{\text {th }}$ edition, Vol. 2. SAS Inst. Inc., Cary, North Carolina.

Schisler, D.A., and R.G. Linderman. 1989a. Selective influence of volatiles purged from coniferous forest and nursery soils on microbes of a nursery soil. Soil Biol. Biochem. 21 : 389-396.

Schisler, D.A., and R.G. Linderman. 1989b. Response of nursery soil microbial population to volatiles purged from soil around Douglas fir ectomycorrhizae. Soil Biol. Biochem. $21: 397-401$.

Sinclair, W.A., D.P. Cowles, and S.M. Hee. 1975. Fusarium root rot of Douglas fir seedlings : suppression by soil fumigation, fertility management and inoculation with spores of the fungal symbiont Laccaria laccata. For. Sci. 21 : 390-399.

Singh, V., and B.J. Deverall. 1984. Bacillus subtilis as a control agent against fungal pathogens of citrus fruit. Trans. Br. Mycol. Soc. 83 : 487-490. 
Singh, N., and R.S. Singh. 1983. Chlamydospore formation in Fusarium nudum by soil bacteria. Ind. Phytopathol. 36 : 165167.

Stack, R.W., and W.A. Sinclair. 1975. Protection of Douglas-fir seedlings against Fusarium root rot by a mycorrhizal fungus in absence of mycorrhiza formation. Phytopathology $65: 468-472$.

Sutherland, J.R., and E. Van Eerden. 1980. Diseases and insects pests in British Columbia forest nurseries. B.C. Min. For., Victoria, B.C. and Can. For. Serv., Pac. For. Res. Cent., Victoria, B.C., Canada. Joint Report 12. 85 pp.

Sylvia, D.M., and W.A. Sinclair. 1983a. Suppressive influence of Laccaria laccata on Fusarium oxysporum and on Douglas fir seedlings. Phytopathology 73 : 384-389.

Sylvia, D.M., and W.A. Sinclair. 1983b. Phenolic compounds and resistance to fungal pathogens induced in primary roots of Douglas fir seedlings by the ectomycorrhizal fungus Laccaria laccata. Phytopathology $73: 390-397$.
Utkhede, R.S. 1984. Effect of bacterial antagonists on Phytophthora cactorum and apple crown rot. Phytopathol. Z. 109 : 169-175.

Utkhede, R.S., and P.L. Sholberg. 1986. In vitro inhibition of plant pathogens by $\mathrm{Ba}$ cillus subtilis and Enterobacter aerogenes and in vivo control of two postharvest cherry diseases. Can. J. Microbiol. 32 : 963-967.

Vanittanakom, N., W. Loeffler, U. Koch, and G. Jung. 1986. Fengycin : a noval antifungal lipopeptide antibiotic produced by $\mathrm{Ba}$ cillus subtilis F-29-3. J. Antibiotics 39 : 888901.

Zak, B. 1964. Role of mycorrhizae in root disease. Annu. Rev. Phytopathol. 2 : 377-392.

Zar, J.H. 1984. Biostatistical analysis. $2^{\text {nd }}$ ed. Prentice Hall Inc., Englewood Cliffs, New Jersey. 412 pp. 